\title{
EFFECT OF TEMPERATURE ON EFFICACY OF Beauveria bassiana VUILLEMIN AND Metarhizium anisopliae VAR.ACRIDIUM GAMS AND ROZSPAL AGAINST THE DESERT LOCUST, Schistocerca gregaria (FORSKAL).
}

Rezk, G. N. ${ }^{1}$; H. E. Mohamed ${ }^{1}$; Gehan A. Mohamed ${ }^{2}$ and A. A. AL-mokhlef ${ }^{1}$

1- Plant protection Department, Faculty of Agriculture, Ain Shams University

2- Locust and Grasshopper Research Department, Plant protection Research Institute. Agriculture Research center.

\begin{abstract}
The influence of temperature on efficacy of Beauveria bassiana and Metarhizium anisopliae against the desert locust, Schistocerca gregaria (Forskal), were investigated in the laboratory. Fifth nymphal instar was inoculated by $1.5 \times 10^{3}$ spores/nymph by topical application using micropipette under the pronotum, at $50 \%$ $\mathrm{RH}$. B.bassiana caused mortality for insects at temperature between $22-31^{\circ} \mathrm{C}$, and $25^{\circ} \mathrm{C}$ was the optimum that caused more rapid death and the $L T_{50}$ was 5.3 days. In contrast $M$. anisopliae has wide range of temperature that can caused death until $37^{\circ} \mathrm{C}$, but $28-31^{\circ} \mathrm{C}$ was the optimum temperature and the $\mathrm{LT}_{50}$ was 5 days. At this optimums temperature, four doses $\left(1.5 \times 10^{2}, 1.5 \times 10^{3}, 1.5 \times 10^{4}\right.$, and $1.5 \times 10^{5}$ spore/nymph) were used against $4^{\text {th }}$ and $5^{\text {th }}$ nymphal instars of the desert locust. For $4^{\text {th }}$ nymphal instar, It' was obvious that $M$. anisopliae caused rapid mortality among infected $4^{\text {th }}$ instar nymph comparing with $B$. basiana at all the tested doses except incase of dose $1.5 \times 10^{2}$ spore /nymph, where treated nymph with $B$. bassiana died faster than those treated with $M$. anisopliae. While for the $5^{\text {th }}$ nymphal instar, It' was clear that $M$. anisopliae caused significant rapid mortality comparing with $B$. bassiana in case of dose $1.5 \times 10^{2}$ spore/nymph. While $B$. bassiana caused significant rapid mortality than $M$. anisopliae in case dose $1.5 \times 10^{4}$.

Keywords: Beauveria bassiana; Metarhizium anisopliae var.acridium; Schistocerca gregaria; Entomopathogenic; Temperature.
\end{abstract}

\section{INTRODUCTION}

The desert locust, Schistocerca gregaria (Forskal), is an economically pest in semi and hot arid areas. The deleterious effects of chemical pesticides used to suppress outbreaks of this pest have prompted development of alternative control methods such as microbial control (Prior and street, 1997). Fungal pathogens in the class Deuteromycotina, which can be grown easily in mass culture and which penetrate directly through the host cuticle, were consider to be the most promising agents (Prior and Greathed, 1989). Metarhizium anisopliae and Beauveria bassiana are the most widely encountered pathogens of acridids in Africa that consider as a microbial insecticide against the desert locust (Lomer et al., 1997; Prior and street, 1997).

Two of the most important environmental factors affecting the ability of an entomopathogenic fungus to infect and overcome its host are humidity 
and temperature (Hall and Papierok, 1982; Benz, 1987 and Ferron et al., 1991) .In acridids, the thermal constraints are not only the results of ambient conditions, but also achieved thermal host thermoregulation (Boorstein and Ewald, 1987; Carruthers et al., 1992 and Inglis et al., 1996). In addition, acridids elevate their body temperature higher than ambient by habitat selection, orientation to solar radiation, or both (Chappell and Whitman, 1990; Heinrich, 1993). The objectives of this study were to determine effects temperature on efficacy of Beauveria bassiana and Metarhizium anisopliae var.acridium against fifth nymphal instars of the desert locust.

\section{MATERIALS AND METHODS}

\section{1- Tested insects:}

Fourth and fifth nymphal instars of the desert locust were used. The individuals were taken from stock culture maintained for several generations. Insects were reared in the laboratory according to the technique of (HunterJones, 1961).

\section{2-The entomopathogenic fungi:}

The entomopathogenic fungi, M.anisopliae and B. bassiana were used. The spores of M.anisopliae var. acridium isolate IMI330189, were used kindly provided by (Biological Control Products), South Africa. But $B$. bassiana was provided by nematodes lab in Cairo University.

The entomopathogenic fungi were grown on oat -mealdodin agar (ODA) medium selectively allows the growth of $M$. anisopliae and $B$. bassiana, while inhibiting the growth of the other fungi and bacteria (Beilharaz and Parberry, 1982; Chase et al., 1986). Conidial suspensions were prepared by pouring approximately $5 \mathrm{ml}$ of vegetable oil onto the culture and scraping the fungus away from the agar. This suspension was placed in a sonicator for

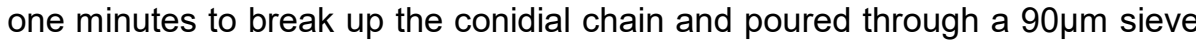
to obtain a conidial suspension free from large mycelia particles .Conidial counts were made using a haemactometer.

\section{3-Effect of temperature on efficacy of entomopathogenic fungi:}

Fifth nymphal instars of 1-2 days old were inoculated by $1.5 \times 10^{3}$ spores/nymph by topical application using micropipette under the pronotum according to prior et al., (1995). Each7 inoculated nymphs were kept in an opened plastic cylinder (diameter $8 \mathrm{~cm}$ and length $25 \mathrm{~cm}$ ) at both ends which covered with a sheet of cloth for ventilation. Fifth temperatures were assessed, 25, 28, 31, 34, and $37^{\circ} \mathrm{C}$ degrees, for M.anisopliae while 21,25 , 28,31 and $34^{\circ} \mathrm{C}$ degrees, for $B$. bassiana. Following inoculation, were placed in incubators. Three replications were used for every treatment and compared with control. The control was treated with $10 \mu \mathrm{l}$ of sterile plant oil and placed in the same temperature of treatment. The insects were fed on Egyptian clover (Trifolium alexandrium). Cadavers were examined for presence of sporulating layer of entomopathogenic. Mortality percentages were calculated after 1- day incubation period after treatment to dead all 
inoculated nymphs. Mortality percentages were corrected by (SchneiderOrelli). Every Nymph died during a bioassay was kept in Petri dishes alone and Incubated at 25C. There were recorded percentages of entomopathogenic which grow on surface body of Nymphs. Percentages mortalities data were subjected to probit analyses according to Finney, (1971), to calculate time mortality responses $L T_{50}, L T_{90}$.

\section{4- Bioassay of the entomopathogenic fungus against nymphal instars of the desert locust:}

Forth and fifth nymphal instars of 1-2 days old were used .The insects were treated by using the same above methods. Four doses were applied for every pathogen. Doses were $1.5 \times 10^{2}, 1.5 \times 10^{3}, 1.5 \times 10^{4}$, and $1.5 \times 10^{5}$ spore/nymph. Treated nymphs were kept at optimum temperature for every fungus. Percentages mortalities were subjected to probit analyses according to Finney, (1971) to calculate, $L T_{50}, L T_{90}$ values and its regression lines.

\section{RESULTS AND DISCUSSION}

1- Effect of temperatures on efficacy of Beauveria bassiana and Metarhizium anisopliae against fifth nymphal instars of the desert locust, S.gergaria.

1-1- Beauveria bassiana:

Data presented in figure (1) showed, the effect of different temperatures on the efficacy of B.bassiana against the fifth nymphal instar of the desert locust, S.gregaria. It's obvious that temperature significantly affected the efficacy of $B$. bassiana against the fifth nymphal instar of the desert locust. Disease development was more rapid among nymphs kept at $25^{\circ} \mathrm{C}$, where insect death started at 4 days after treatment, while started at 5 and 6 days after treatment at $28^{\circ} \mathrm{C}$ and $22^{\circ} \mathrm{C}$ respectively. The mortality among those nymphs kept at $25^{\circ} \mathrm{C}$ reached to $100 \%$ after 7 days of treatment, the medial lethal time $\mathrm{LT}_{50}$ was 5.3 days table (1). While, in case of those nymphs kept at $22,28^{\circ} \mathrm{C}$ the mortality reached to $100 \%$ after 15,16 days after treatment, and the $\mathrm{LT}_{50}$ were 10.1 and 10.6 days respectively, with no significantly difference between 22 and $28^{\circ} \mathrm{C}$. Although the mortality among nymphs kept at $31^{\circ} \mathrm{C}$ reached to $40 \%$ after 20 days of treatment and the $\mathrm{LT}_{50}$ was 28.6 days. There was no mortality among the nymphs kept at 34 ${ }^{\circ} \mathrm{C}$. 
Rezk, G. N. et al.

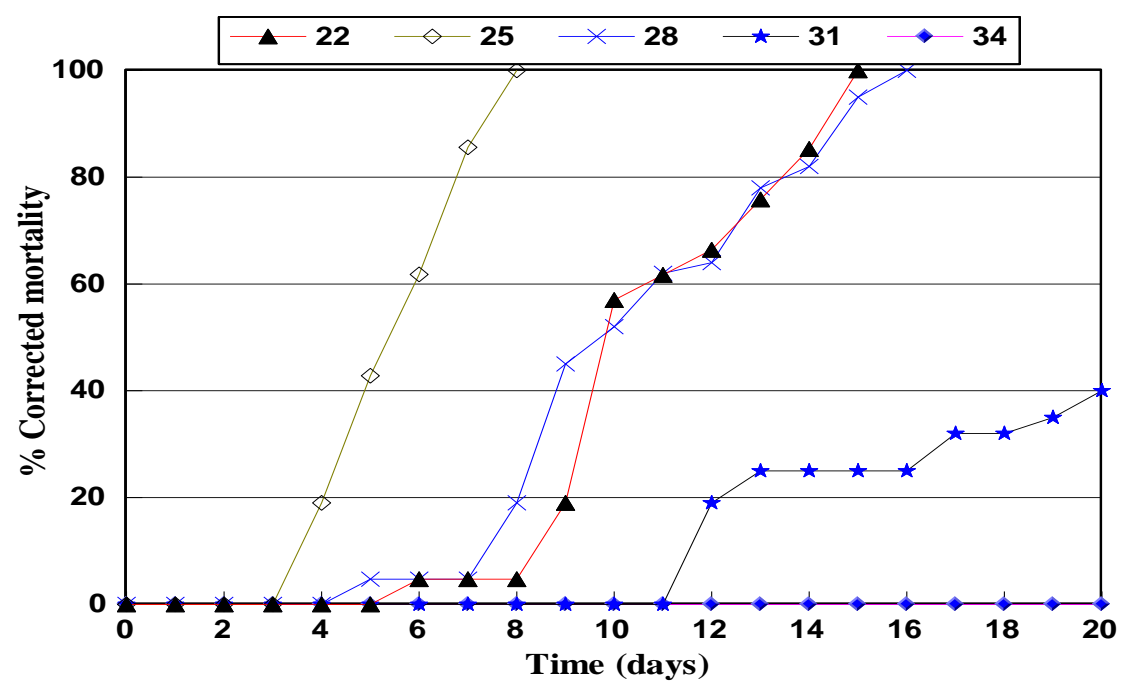

Fig (1): Effect of temperatures on efficacy of B.bassiana against of the 5th nymphal instars of the desert locust, S. gregaria

\section{1-2- Metarhizium anisopliae:}

Data illustrated in figure (2) showed the effect of different temperatures on the efficacy of $M$. anisopliae against the fifth nymphal instar of the desert locust, S.gergaria. These data clearly showed that there were significant differences between mortalities of the nymphs kept on different temperature. Disease development was more rapid at temperature 28 and $31^{\circ} \mathrm{C}$. The death started at $4^{\text {th }}$ day when nymphs kept at $25,28,31^{\circ} \mathrm{C}$ and $34^{\circ} \mathrm{C}$ while started at $9^{\text {th }}$ day for nymphs kept at $37^{\circ} \mathrm{C}$. It's obvious that the mortality among treated nymphs reached to $100 \%$ after $11,8,7,11$, and 17 days of treatment when kept at $25,28,31,34$, and $37^{\circ} \mathrm{C}$ respectively. The $\mathrm{LT}_{50}$ was 5.1 days for nymphs kept at 28 and $31^{\circ} \mathrm{C}$ table (1). On the other hand nymphs that kept at 25 and $24^{\circ} \mathrm{C}$, the $\mathrm{LT}_{50}$ were 10.1 and 10.6 days respectively. In contrast the $L T_{50}$ was 28.6 day for the nymphs kept at $34^{\circ} \mathrm{C}$. From figures 1 and 2 concluded that the optimum temperature for the efficacy of $B$. bassiana is $25^{\circ} \mathrm{C}$, while for $M$. anisopliae was between $28-31^{\circ} \mathrm{C}$.

These findings go in line with the results of Shashi-Sharma et al., (1998), who found that $B$. bassiana could grow within the temperature range $20-28^{\circ} \mathrm{C}$, but $25^{\circ} \mathrm{C}$ was the most suitable temperature for conidial production. Ekesi et al., (1999), studied in the laboratory the effect of temperature on germination, radial growth and pathogenic activity of two strains of $B$. bassiana and four strains of $M$. anisopliae on the legume flower thrips, Megalurothrips sjostedti. Germination, radial growth and pathogenic activity were low for all strains at $15^{\circ} \mathrm{C}$. Optimum temperature for germination, radial growth and pathogenic activity ranged between $25-30^{\circ} \mathrm{C}$. The fastest growing strain at $25-30^{\circ} \mathrm{C}$ was $M$. anisopliae strain ICIPE 69 , compared to other strains. Berlanga-Padilla et al., (2002) determined the optimal temperature for germination and growth $B$. bassiana isolates was between 24 
and $30{ }^{\circ} \mathrm{C}$. At $26^{\circ} \mathrm{C}, B$. bassiana caused $88 \%$ mortality in S. p. piceifrons, and LT 50 were 5.9 days. Inglis et al., (1997) also observed that at constant $35^{\circ} \mathrm{C}$, over $80 \%$ mortality was obtained in Melanoplus sanguinipes (Fab.), whereas less than $10 \%$ mortality was obtained when the grasshoppers were kept at $40^{\circ} \mathrm{C}$ for $12 \mathrm{~h} /$ day. Interestingly, Fargues et al., (1997) determined the effects of temperature on conidial germination and susceptibility of adults of $S$. gregaria, to four isolates of Metarhizium flavoviride. There were differences among the isolates in the effects of temperature on germination of conidia after a 24-h incubation period. Over $90 \%$ of conidia of all isolates germinated after $24 \mathrm{~h}$ at $30^{\circ} \mathrm{C}$. In contrast, at $40^{\circ} \mathrm{C}$, none of the isolates germinated for up to $72 \mathrm{~h}$. However, there were differences in germination between the isolates at $35^{\circ} \mathrm{C}$. Locust mortality and disease progression were significantly affected by temperature. At both $25^{\circ} \mathrm{C}$ and $30^{\circ} \mathrm{C}$, all isolates induced $98-100 \%$ mortality within 8 days; however, there were differences between isolates at $35^{\circ} \mathrm{C}$. None of the isolates caused significant mortality at $40^{\circ} \mathrm{C}$.

Table (1): $L T_{50}$, $L T_{90}$, values of 5 th nymphal instars of the desert locust, S.gregaria, treated with B.bassiana and M. anisopliae, at different temperature.

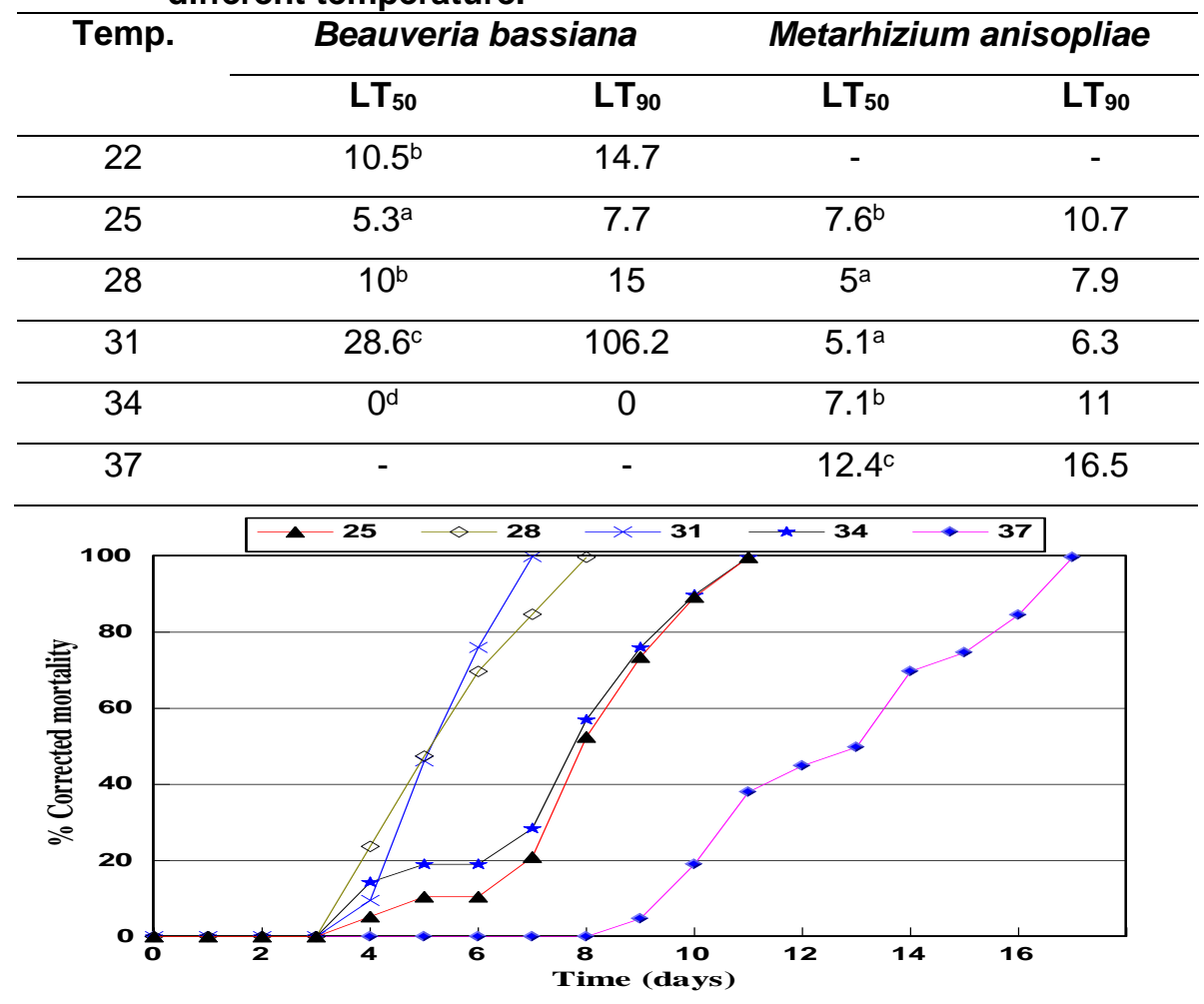

Fig (2): Effect of temperatures on efficacy of M.anisopliae against the $5^{\text {th }}$ nymphal instars of the desert locust, $S$. gregaria. 
Rezk, G. N. et al.

2-Bioassay of $B$. bassiana, M. anisopliae against the $4^{\text {th }}, 5^{\text {th }}$ nymphal instars of the desert locust.

2-1-fourth nymphal instar:

Table (2) showed the time mortality response of $B$. bassiana and $M$. anisopliae on the $4^{\text {th }}$ nymphal instar of $S$. gregaria, expressed of the time required to kill 50 and $90 \%$ of the treated nymph ( $\mathrm{LT}_{50}$ and $\left.\mathrm{LT}_{90}\right)$. It's clear that $\mathrm{LT}_{50}$ of treated nymph with $B$. bassiana were: $5.51,6.33,7.5$ and 8.97 days, while these values for nymphs treated with $M$. anisopliae were $4.47,5.28,6.32$ and 12.03 days after treatment with doses $1.5 \times 10^{5}, 1.5 \times 10^{4}$, $1.5 \times 10^{3}, 1.5 \times 10^{2}$ spore/nymph, respectively. The slopes of the linear regression of the mortality versus time for B.bassiana were 3.5, 7.84, 6.29 and 4.14 and for $M$. anisopliae were $6.9,9.02,10.8$ and 3.3. It could be concluded that $M$. anisopliae caused rapid mortality among infected $4^{\text {th }}$ instar nymph comparing with $B$. basiana at all the tested doses except incase of dose $1.5 \times 10^{2}$ spore /nymph. Treated nymph with $B$. bassiana died faster than those treated with $M$. anisopliae. It's obvious that dose $1.5 \times 10^{5}$ of B.bassiana has significantly lower $\mathrm{LT}_{50}$ than dose $1.5 \times 10^{3}$ and significantly lower than of dose $1.5 \times 10^{2}$. While in case of $M$. anisopliae there were significant differences between each dose and other and could by arranged in ascending order as follows $1.5 \times 10^{5}>1.5 \times 10^{4}>.5 \times 10^{3}>.5 \times 10^{2}$. The slope of $B$.bassiana regression line with dose $1.5 \times 10^{5}$ was the lowest value indicating the lowest degree of homogeneity of these insects for their susceptibility to this fungus. On contrary, the slope regression line with dose $1.5 \times 10^{4}$ was the highest value indicating the highest degree of homogeneity for susceptibility of the 4th nymphal instars of the locust, S.gregaria to this fungus

Table (2): $\mathbf{L T}_{50}, \mathbf{L} T_{90}$, values of $4^{\text {th }}$ nymphal instars of the desert locust, S.gregaria, treated with B.bassiana and M. anisopliae, at different doses.

\begin{tabular}{lcccccc}
\hline \multirow{2}{*}{ Doses $^{*}$} & \multicolumn{3}{c}{ B.bassiana } & \multicolumn{3}{c}{ M.anisopliae } \\
\cline { 2 - 7 } & $\mathbf{L T}_{50}$ & $\mathbf{L T}_{90}$ & Slope & LT $_{50}$ & LT $_{90}$ & Slope \\
\hline $1.5 \times 10^{5}$ & $5.51^{\mathrm{CA}}$ & 12.67 & $3.55 \pm 0.6$ & $4.47^{\mathrm{dB}}$ & 6.85 & $6.9 \pm 0.48$ \\
\hline $1.5 \times 10^{4}$ & $6.33^{\mathrm{CA}}$ & 9.22 & $7.84 \pm 0.57$ & $5.28^{\mathrm{cB}}$ & 7.33 & $9.02 \pm 0.71$ \\
\hline $1.5 \times 10^{3}$ & $7.5^{\mathrm{bA}}$ & 12 & $6.29 \pm 0.57$ & $6.32^{\mathrm{bB}}$ & 8.43 & $10.8 \pm 0.58$ \\
\hline $1.5 \times 10^{2}$ & $8.97^{\mathrm{aA}}$ & 18.28 & $4.14 \pm 0.22$ & $12.03^{\mathrm{aB}}$ & 29.41 & $3.3 \pm 0.14$ \\
\hline
\end{tabular}

*Conidia/nymph

$\mathbf{L T}_{50}$ with same small letters did not differ significant in the same fungi.

$\mathbf{L T}_{50}$ with same cab letters did not differ significant in the same dose. 


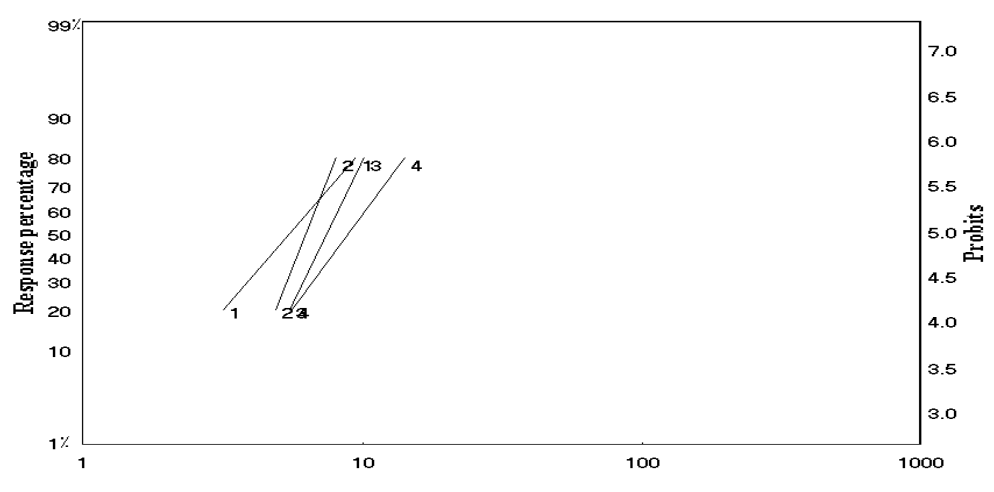

Log times

Fig. 3: Toxicity regression lines of B.bassiana against the $4^{\text {th }}$ nymphal instars of the desert locust, S.gregaria.

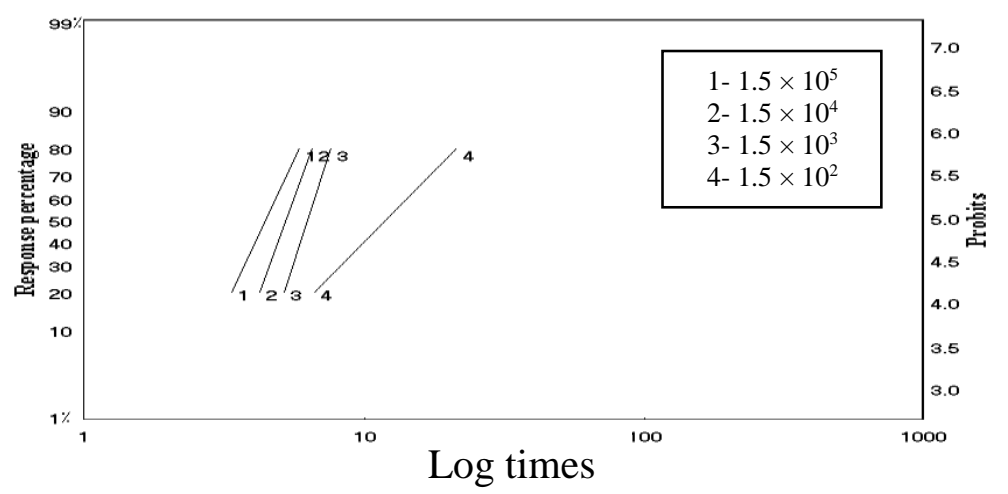

Fig. 4 : Toxicity regression lines of $M$.anisopliae against the $4^{\text {th }}$ nymphal instars of the desert locust, S.gregaria..

\section{2-2-fifth nymphal instar:}

Table (3) shows the time mortality response of $B$. bassiana and $M$. anisopliae against the $5^{\text {th }}$ nymphal instar of $S$. gregaria, expressed of the time required $\mathrm{LT}_{50}$ and $\mathrm{LT} T_{90}$. Its clear that $\mathrm{LT}_{50}$ of treated nymph with $B$. bassiana were: $4.51,4.16,6.66$ and 14.2 days while these values for treated nymphs with $M$. anisopliae were $4.84,5.36,6.53$ and 9.12 days after treatment with doses $1.5 \times 10^{5}, 1.5 \times 10^{4}, 1.5 \times 10^{3}, 1.5 \times 10^{2}$ respectively. The slopes of the linear regression of the mortality versus time for B.bassiana were 7.3, 7.5, 7.5 and 4.3 and for $M$. anisopliae were 6.72, 7.45, 7.79 and 10.08. It's clear that $M$. anisopliae caused significant rapid mortality comparing with $B$. bassiana in case of dose $1.5 \times 10^{2}$ spore/nymph. While $B$. bassiana caused significant rapid mortality than $M$. anisopliae in case dose $1.5 \times 10^{4}$. In both fungus, doses $1.5 \times 10^{5}, 1.5 \times 10^{4}$ have significant lower $\mathrm{LT}_{50}$ than dose $1.5 \times 10^{3}$. While $1.5 \times 10^{3}$ was significant lower than dose $1.5 \times 10^{2}$ spore/nymph. The slope of M.anisopliae regression line with dose $1.5 \times 10^{2}$ was the lowest value indicating 
Rezk, G. N. et al.

the lowest degree of homogeneity of these insects for their susceptibility to this fungus. On contrary the slope regression line with dose $1.5 \times 10^{3}$ was the highest value indicating the highest degree of homogeneity for susceptibility of the $5^{\text {th }}$ nymphal instars of the desert locust, S.gregaria to this fungus.

Table (3): $\mathbf{L T}_{50}, \mathbf{L} T_{90}$, values of $5^{\text {th }}$ nymphal instars of the desert locust, S.gregaria, treated with B.bassiana and M. anisopliae, at different doses.

\begin{tabular}{|l|c|c|c|c|c|c|}
\hline \multirow{2}{*}{ Doses $^{*}$} & \multicolumn{3}{|c|}{ B.bassiana } & \multicolumn{3}{c|}{ M.anisopliae } \\
\cline { 2 - 7 } & $\mathbf{L T}_{\mathbf{5 0}}$ & LT $_{\mathbf{9 0}}$ & Slope & LT $_{\mathbf{5 0}}$ & LT $_{\mathbf{9 0}}$ & Slope \\
\hline $1.5 \times 10^{5}$ & $4.51^{\mathrm{cA}}$ & 6.75 & $7.3 \pm 0.63$ & $4.84^{\mathrm{cA}}$ & 6.72 & $8.99 \pm 0.74$ \\
\hline $1.5 \times 10^{4}$ & $4.16^{\mathrm{cB}}$ & 6.15 & $7.5 \pm 0.58$ & $5.36^{\mathrm{cA}}$ & 7.45 & $8.98 \pm 0.88$ \\
\hline $1.5 \times 10^{3}$ & $6.66^{\mathrm{bA}}$ & 9.85 & $7.5 \pm 0.5$ & $6.53^{\mathrm{bA}}$ & 7.79 & $16.72 \pm 1.22$ \\
\hline $1.5 \times 10^{2}$ & $14.2^{\mathrm{aA}}$ & 28.18 & $4.3 \pm 0.19$ & $9.12^{\mathrm{aB}}$ & 15.08 & $5.86 \pm 0.29$ \\
\hline
\end{tabular}

-LT 50 with same small letters did not differ significant in the same fungi.

-LT ${ }_{50}$ with same cab letters did not differ significant in the same dose

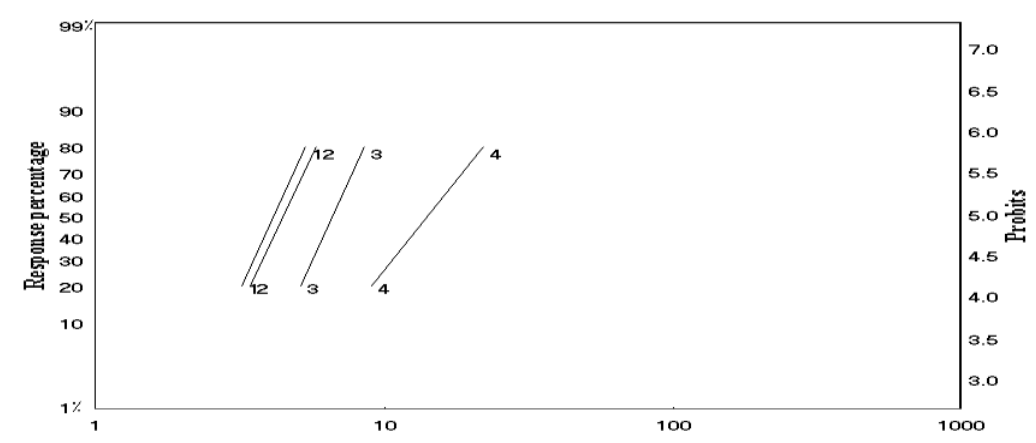

Fig. 5: Toxicity regression lines of $B$.bassiana against the $5^{\text {th }}$ nymphal instars of the desert locust, S.gregaria.

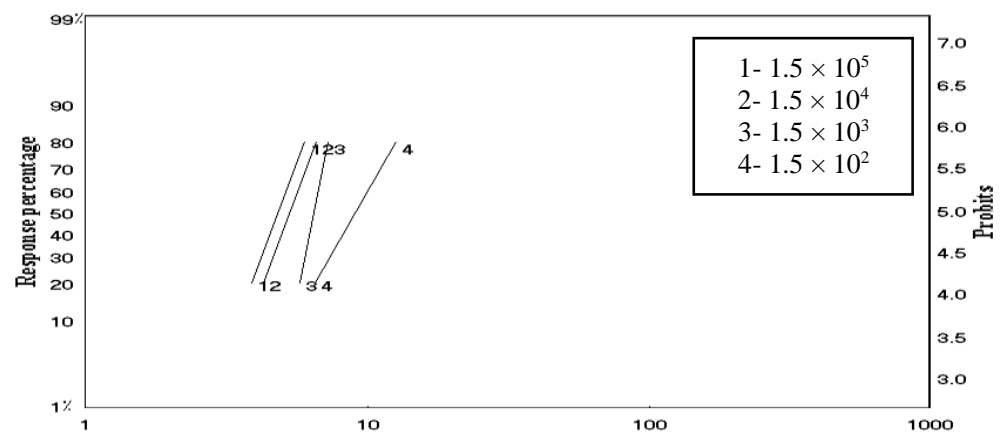

Log times

Fig. (6): Toxicity regression lines of M.anisopliae against the $5^{\text {th }}$ nymphal instars of the desert locust, S.gregaria. 
These findings go in line with the results of Moore and Erlandson, (1988), who assessed B.bassiana against the nymphs of the grasshopper, Melanopuls sanguiniipes (Fabricius) by topical oral and injected applications $1.5 \times 10^{3}, 1.5 \times 10^{4}$ and $1.5 \times 10^{5}$ spore/nymph. B.bassiana caused high mortality (82-100\%) at all doses tested, between 3-5 days after applied the fungus. Tefera and Pringle, (2003) tested isolates of B.basiana and M.anisopliae against the spotted stalk borer, Chilo partellus (Swinhoe). All isolates induced $100 \%$ mortality to $C$. partellus larvae in six days. Moore et al., (1992) showed that M.flavoviride killed adults' of S.gregaria, with dose 80.000 conidia /insect at $30^{\circ} \mathrm{C}$ in 5-9 days. Prior et al., (1992) used 75000 spore / insect of M.anisopliae against of S.gregaria. At this dose the fungus killed $50 \%$ of the test insect in 4-5 days. Also this results corresponds exactly with ( Lomer et al., 1999) when they used spraying the Niger isolate of M.anisopliae against fourth instars hopper bands of the desert locust , S.gregaria .The nymphs of the desert locust gave up to $90 \%$ mortality in $9^{\text {th }}$ day after spraying. On the other hand, work carried out on B.basiana in the United States (Foster et al., 1992) and in Canada (Inglis et al., 1993) and on M.flavoviride in Africa (Bateman et al., 1994) has indicated that secondary pick- up takes place .In a trial on Zonocerus variegates (L.) where application was very satisfactory. The speed kill in the field has only been 1-2 days slower than expected from laboratory. These findings go in line with the results of (Lobolima et al., 1992; Johnsone et al., 1992) who tested the fungus B.basiana against Oedaleus senegalensis. The fungus caused a statistically significant mortality when sprayed directly against the insects in the field. Also these results are consistent with those of (Berlanga-Padilla and Hernandez, 2002) who showed that at 26 degree B.bassiana caused $76 \%$ mortality in adults of Schistocerca piceifrons piceifrons (Orthoptera: Acrididae) and their half lethal time (LT50) was 5.2 days. Milner and Prior, (1994) stated that most mortality with two isolates of M.flavoviride against 4th instars of Chortoiecetes terminifera with dose $3.75 \times 10^{7}$ occurred between 46 days, while $\mathrm{LT}_{50}$ was the 4.3 days for isolate FI985. While isolates FI610 killed almost all the insects at 5 days. $\mathrm{LT}_{50}$ was 6.7. Also (Bateman et al., 1996) screened the pathogenicity of 159 isolates of Metarhizium spp and Beauveria. spp against Schistocerca gregaria adults. All screens included a standard strain of Metarhizium spp. (from a single spore of IMI 330189ss), which gave an average $L T_{50}$ value of 4.4 days in 46 assays. Approximately 50 isolates, all belonging to the genus Metarhizium, showed virulence that was comparable with this strain.

\section{REFERENCES}

Bateman, R .; M. Carey; D. Batt.; C. Prior; Y. Abraham; D. Moore; N. Jenkins and $J$. Fenlon. (1996). Screening for virulent isolates of entomopathogenic fungi against the desert locust, Schistocerca gregaria (Forskal). Biocontrol Science and Technology, 6: 4. 549- 560. 
Bateman, R. P.; R. E. Price; E. J. Muller, and H. D. Brown. (1994). Controlling brown locust hopper bands in South Africa with a myco-insecticide spray. PP609-616.in Brighton crop protection conference, pests and Disease 1994.British Crop protection Council, Farnham, UK.

Beilharaz, V. C. and D. G. Parberry. (1982). A selective agent for certain soil fungi .Trans .Brit.Mycol.Soc.79:3.507-511.

Benz, G. (1987): Environment, in Epizootiology of Insect Disease (Fuxa, J. R. and Tanda, Y., Eds) John Wiley and Sons, New York,pp.177-214.

Berlanga-Padilla, A. M. and V. M. Hernandez-Velazquez. (2002). Effect of temperature on the growth and virulence of Metarhizium anisopliae, var. acridum and Beauveria bassiana on Schistocerca piceifrons piceifrons. Manejo Integrado de Plagas. 63. 51-55 (ab).

Boorestein, S. M. and P. W. Ewald. (1987). Costs and benefits of behavioral fever in Melanoplus sanguinipes infected by Nosema acidophilus .Physiological Zoology,60. 675-663.

Carruthers, R. I.; T. S. Larkin, and H. Firstencel. (1992). Influence of thermal ecology on the mycosis of a rangeland grasshopper.Ecology 73,190204.

Chappell, M. A. and D. W. Whitman. (1990). Grasshoppers thermo regulating ,pp.143-172.In chapman(ed).Biology of grasshoppers.Wiley, New York.

Chase, A. R.; L. S. Osborne. and V. M. Ferguson (1986). Selective isolation of the entomopathogenic fungi Beauveria basiana and Metarhizium anisopliae from an artificial potting medium .Florida. Entomologist .69:2. 285-292.

Ekesi, S.; N. K. Maniania and K .Ampong Nyarko. (1999). Effect of temperature on germination, radial growth and virulence of Metarhizium anisopliae and Beauveria bassiana on Megalurothrips sjostedti. Biocontrol Science and Technology. 9:2. 177-185.

Fargues, J.; A. Ouedraogo; MS. Goettel and CJ. Lomer. (1997). Effects of temperature, humidity and inoculation method on susceptibility of Schistocerca gregaria to Metarhizium flavoviride. Biocontrol Science and Technology. 7: 3. 345- 356.

Ferron, P.; J. Fragues, and G. Riba. (1991). Fungi as biological insecticides against pests, in handbook of Applied Mycology: Humans, Animals, and Insects .Marcel Dekker, New York,pp613-633 .

Finney, D. J. (1971): Probit Analysis. Cambridge University Press, Cambridge.

Foster, R. N.; K. C. Reuter; C. A. Bradley, and P. P. Wood. (1992). Preliminary investigations on the effect of Beauveria bassiana on several species of rangeland grasshoppers. USDA Cooperative Grasshoppers Integrated Pest Management Project 1991. Annual Report. 203- 210.

Hall, R. A. and B. Papierok. (1982). Fungi as biological control agents of arthropods of agricultural and medial importance. Parasitology. 84, 205-204.

Heinrich, B.(1993): The hot -blooded insects .Harvard university press. Cambridge, MA. 
Hunter-jonse, p. (19961). Rearing and breading locusts in the laboratory .Buull.Anti Locust Res.Center,London $.12 \mathrm{pp}$.

Inglis, G. D.; D. L. Johnson, and M. S. Goettel. (1997). Effects of temperature and thermoregulating on mycosis by Beauveria bassiana in grasshoppers. Biological control7, 131-139.

Inglis, G. D.; D. L. Johnson; K. J. Cheng and M. S. Goettel. (1997). Use of pathogen combinations to overcome the constraints of temperature on entomopathogenic hyphomycetes against grasshoppers. Biological Control. 8:2.143-152.

Inglis, G. D.; M. S. Goettel; and D. L. Johnson. (1993). Persistence of the entomopathogenic fungus, Beauveria bassiana on Phylloplanes of crested wheatgrass and alfalfa. Biological Control 3:258-270.

Johnson, D. L.; M .S. Goettel.; C. Bradley; H. van der Paaw, and B. Maiga. (1992). Field trials with entomopathogenic fungus Beauveria basiana against grasshopper in Mali ,West Africa, July 1990.pp.296-310 in Lomer, C. J., and C. Prior .Biological Control of Locust and Grasshopper .CAB International .UK.394 PP.

Lobo Lima, M. L.; J. M. Brito, and J. E. Henry. (1992). Biological control of grasshoppers in the Cape Verde Islands.287-295 pp. In Lomer, C. J.; and C. Prior (EDS), Biological control of locust and grasshoppers .CAB International, UK, 394 PP.

Lomer, C. J.; C. Prior and C. Kooyman. (1997). Development of Metarhizium spp. for the control grasshoppers and locusts, in Microbial Control of Grasshoppers and (Goettel, M.S. and Johnson, D. L., Eds) Memoirs Entomological Society of Canada. Prior, C. and D. J. Greathead. (1989): Biological control of locust the potential for the exploitation of pathogens. FAO Plant Prot.Bull.37, 37-48.

Lomer, C. J.; RP. Bateman.; D. Dent.; H. de. Groote; OK. Douro Kpindou; C. Kooyman.; J. Langewald.; Z. Ouambama.; R. Peveling; M. Thomas and H. de.Groote. (1999). Development of strategies for the incorporation of biological pesticides into the integrated management of locusts and grasshoppers. Agricultural and Forest Entomology. 1: 2, 71-88.

Milner, R. and C. Prior. (1994). Susceptibility of the Australian plague locust Chortoicetes terminifera, and the wingless grasshopper, Phaulacridium vittatum, to the fungi Metarhizium spp. Biological Control. 4: 2.132-13.

Moore, K. C. and M. A. Erandson. (1988). Isolation of Aspergillus parasiticus and Beauveria bassiana from melanpline grasshoppers and demonstrate of their pathogenicity in Melanoplus sanguinipes, (Fabricus). Canadian Entomology 120, 989-991.

Moore, D.; M. Reed ; Patourel, G. le.; YJ. Abraham; C. Prior; Le. Patourel-G. (1992). Reduction of feeding by the desert locust, Schistocerca gregaria, after infection with Metarhizium flavoviride. Journal of Invertebrate Pathology. 60: 3. 304- 307.

Prior, C. and D. A. Streett. (1997). Strategies for the use of entomopathogens in the control of the desert locust and other a cridid pests, in Microbial of Grasshoppers and Locusts (Goettel, M.S. and Johnson, D. L., Eds) Memoirs Entomological Society of Canada. 
Rezk, G. N. et al.

Prior, C.; M .Carey; Y. J. Abraham; D. Moore. and RP. Bateman. (1995). Development of a bioassay method for the selection of entomopathogenic fungi virulent to the desert locust, Schistocerca gregaria (Forskal). Journal of Applied Entomology. 119: 8, 567-573.

Prior, C.; C. J. Lomer; H. Herren; A. Paraiso; C. Kooyman; and H. Smith. (1992). The IBC/IITA/DFPV collaborative research programme on the biological control of locust and grasshoppers.pp8-20.

Shashi-Sharma; R. B. L. Gupta and C. P. S .Yadava. (1998). Effect of temperatures on growth, sporulation and bioactivity of entomofungi against whitegrub, Holotrichia consanguinea. Indian Journal of Entomology. 601. 1-7.

Tefera, T and K. Pringle. (2003). Germination, radial growth, and sporulation of Beauveria bassiana and Metarhizium anisopliae isolates and their virulence to Chilo partellus (Lepidoptera: Pyralidae) at different temperature. Biocontrol Science and Technology. 13:7. 699-704.

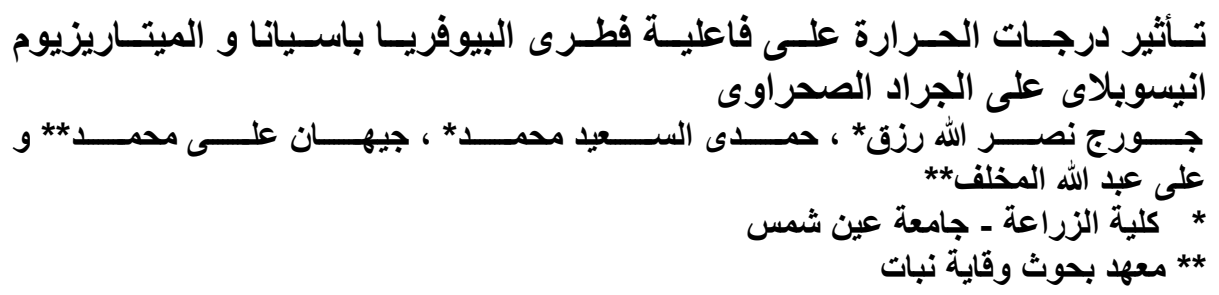

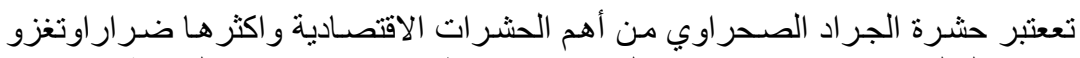

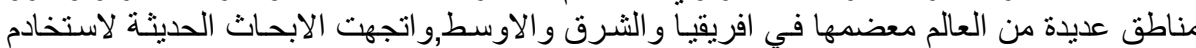

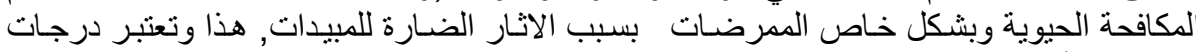

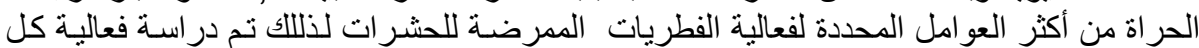

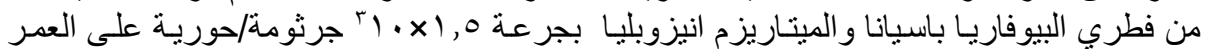

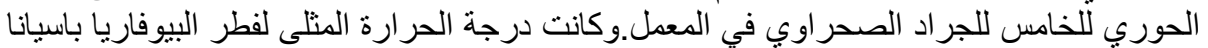

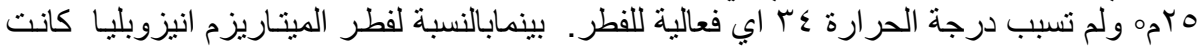

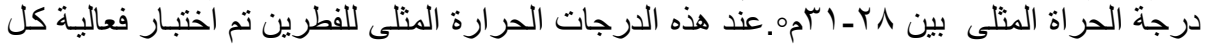

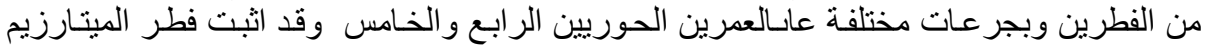
فعالية اعلى من فطر البيوفاريا عند الجرعات الاعلى بينما في الجرعة الإقل حدث العبن العكس. 